Article

\title{
Substrate Chemistry and Rainfall Regime Regulate Elemental Composition of Tree Leaves in Karst Forests
}

\author{
Ernesto Medina ${ }^{1,2,3, *}$, Elvira Cuevas ${ }^{3}$ and Ariel E. Lugo ${ }^{1}$ \\ 1 International Institute of Tropical Forestry (IITF), USDA Forest Service, Rio Piedras 00926-1115, Puerto Rico; \\ alugo@fs.fed.us \\ 2 Centro de Ecología, Instituto Venezolano de Investigaciones Científicas, Altos de Pipe 1020A, Venezuela \\ 3 Departmento de Biología, Universidad de Puerto Rico, San Juan 00926; Puerto Rico; epcuevas@gmail.com \\ * Correspondence: medinage@gmail.com; Tel.: +1-787-755-5637
}

Academic Editor: Timothy A. Martin

Received: 15 April 2017; Accepted: 20 May 2017; Published: 25 May 2017

\begin{abstract}
Forests on calcareous substrates constitute a large fraction of the vegetation in Puerto Rico. Plant growth on these substrates may be affected by nutrient deficiencies, mainly $\mathrm{P}$ and Fe, resulting from high $\mathrm{pH}$ and formation of insoluble compounds of these elements. The occurrence of these forests in humid and dry areas provides an opportunity to compare nutrient relations, water use efficiency, and $\mathrm{N}$ dynamics, using biogeochemical parameters. We selected sites under humid climate in the north, and dry climate in the southwest of Puerto Rico. Adult, healthy leaves of species with high importance values were collected at each site and analyzed for their elemental composition and the natural abundance of $\mathrm{C}$ and $\mathrm{N}$ isotopes. Calcium was the dominant cation in leaf tissues, explaining over $70 \%$ of the ash content variation, and $\mathrm{Al}$ and $\mathrm{Ca}$ concentration were positively correlated, excepting only two Al-accumulating species. Karst vegetation consistently showed high N/P ratios comparable to forests on P-poor soils. Dry karst sites had significantly higher $\delta^{13} \mathrm{C}$ and $\delta^{15} \mathrm{~N}$ ratios. We conclude that forests on karst are mainly limited by $\mathrm{P}$ availability, and that mechanisms of nutrient uptake in the rhizosphere lead to linear correlations in the uptake of $\mathrm{Ca}$ and Al. Isotope ratios indicate higher water use efficiency, and predominant denitrification in dry karst forest sites.
\end{abstract}

Keywords: tropical karst; element concentration; N/P ratios; $\mathrm{Ca} / \mathrm{Al}$ relationship; $\delta^{13} \mathrm{C} ; \delta^{15} \mathrm{~N}$

\section{Introduction}

Limestone areas are widespread in the Caribbean under dry to subhumid climatic conditions. Those areas developed mostly during the middle Oligocene to the middle Pliocene and have been documented extensively in Jamaica, Cuba, Santo Domingo, and Puerto Rico [1-6]. Several forest types, from dry to moist, covering large areas of those geologic formations, have been described in detail in many locations [4,7-9].

In Puerto Rico, karst areas constitute about $27 \%$ of the territory and are separated as moist karst forming a northern belt crossing the island from east to west, and a dry karst formation in the southwest, under semiarid climate [4]. These formations have a similar geological age (Pliocene-Oligocene) but are under different rainfall regimes [10]. The limestone formations are covered throughout the island by sediments constituted by non-calcareous material that, in the northern karst belt, accumulate in depressions between haystack (mogotes) hills [10,11]. On top of the mogotes in the karst belt, or on the calcareous hills of the southern karst, this material may accumulate within crevices and fractures of the calcareous strata. Surface soils in karstic areas, when present, are highly heterogeneous, frequently 
shallow, and, in many cases, difficult to sample. Soils derived from the calcareous substrate itself are infrequent. On ridge tops and slopes, soil is almost inexistent, and substrate is a rocky, partially fragmented surface, covered with organic residues produced by the vegetation. Fragments of the carbonaceous rock and organic matter slide downhill and accumulate in the valleys $[4,11,12]$. On the valleys, true soils develop constituted by calcareous rocks fragments and the remaining material transported from volcaniclastic areas during the time when the carbonate rocks were under water (see [11] for an explanation of the composition of blanket sands). Assessment of nutrient availability for plants on the ridge top sites using soils as reference is therefore not a practical approach. The alternative is the analysis of plant organs, particularly leaves [13].

Nutrient availability for plant growth in soils derived from carbonate rocks is usually limited, particularly in $\mathrm{P}$, as it tends to be immobilized as Ca compounds of low solubility [14]. High soil pH determines lower mobility of elements such as $\mathrm{Mn}$ and $\mathrm{Fe}$, resulting in potential limitation for plant growth (Ca induced iron chlorosis). The nutrient relationships of plants from calcareous substrates have been mainly studied in temperate climates [15] and little is known from tropical vegetation [16].

Typical vegetation of moist karst forests has been described by Alvarez et al. [17] and Acevedo-Rodríguez and Axelrod [18] and that of the dry karst forest was studied by Murphy and Lugo [19], and documented in detail by Monsegur [20].

Our study took advantage of detailed phytosociological analysis of the northern karst vegetation undertaken by Chinea [21] and Aukema et al. [22]. In the latter, the authors quantified the composition of forest units according to species dominance relationships and geomorphological positions on the mogotes (top, slopes, valleys). This study was critical to the identification of tree assemblages on the top of mogotes. In addition, we used the vegetation analysis of Murphy and Lugo [19] and Molina and Lugo [23] for the Guánica dry forest in southern Puerto Rico. The dominant tree species in typical sites of northern and southern karts areas, as defined by their importance value, reveals the occurrence of common and restricted species. For example, Coccoloba diversifolia (Polygonaceae) and Gymnanthes lucida (Euphorbiaceae) occur as dominant species in both moist and dry karst, whereas Pisonia albida (Nyctaginaceae), Thouinia portoricensis (Sapindaceae), and Pictetia aculeata (Fabaceae) seem to be restricted to dry karst forests, and Lonchocarpus lancifolius (Fabaceae), and Prunus myrtifolia (Rosaceae) are restricted to the northern moist karst belt [24].

The objective of the present study was to provide a geochemical characterization of the karst areas in the island of Puerto Rico through the elemental analysis of substrate and plant leaves. Leaf analyses provide information on both the availability of specific elements in the soil solution, and reveal physiological properties such as exclusion or facilitation of element uptake at the root level [13]. We tested hypotheses related to the leaf elemental composition, substrate geochemistry, and environmental humidity: (1) Ca is the main component of leaf ash due to its expected high availability in the calcareous substrate; (2) Lower total $\mathrm{P}$ concentrations and high $\mathrm{N}$ to $\mathrm{P}$ ratios reflect relative limited availability of $\mathrm{P}$, probably associated with the formation of insoluble Ca compounds; (3) Concentrations of heavy metals ( $\mathrm{Fe}$ and $\mathrm{Mn}$ ) and $\mathrm{Al}$, are probably low compared to species from forests on non-calcareous substrates; (4) Environmental humidity determined by seasonality and magnitude of rainfall affect plant water use efficiency and rate of organic $\mathrm{N}$ mineralization in the substrate.

\section{Materials and Methods}

For the study of the nutritional relationships of tree species strictly associated with karstic substrates, we selected sites in the humid karst belt and in the semiarid south west karst area in Puerto Rico. The sampling was restricted to plants growing on the top of haystack hills in the northern karst belt, and on ridge sites and coastal carbonate pavement in the southwestern karst area.

We selected six mogote tops sites in the moist northern karst belt and two sites in the dry Guánica forest in southwestern Puerto Rico (Table 1). The former sites were located along a west-east line on the northern karst belt, on top of the Aymamon limestone type, whereas those on the dry karst areas are 
on the Ponce limestone type [10]. The northern karst belt receives, on average, annual rainfall amounts of 1000-1500 mm, whereas in the southern karst areas long-term annual rainfall averages lie below $1000 \mathrm{~mm}$. This contrasting rainfall pattern is clearly exemplified by two stations, Utuado (158 m), located in the middle of the Aymamon karst [10] in the northern karst belt, and Ensenada (46 m), on the southwestern coast, representative for the rainfall regime of the southern karst belt (Figure 1).

Table 1. Karst site locations (Lat, Long) and approximate altitude.

\begin{tabular}{ccccc}
\hline & Karst Site & North Lat $\left(^{\circ}\right)$ & West Long $\left(^{\circ}\right)$ & Altitude $(\mathbf{m})$ \\
\hline \multirow{5}{*}{ Moist sites } & Guajataca & 18.42 & 66.83 & 230 \\
& El Tallonal & 18.41 & 66.73 & 160 \\
& Cambalache & 18.45 & 66.59 & 45 \\
& Río Lajas & 18.40 & 66.26 & 50 \\
& Nevarez & 18.41 & 66.25 & 35 \\
& Hato Tejas & 18.40 & 66.19 & 100 \\
\hline \multirow{2}{*}{ Dry sites } & Guánica ridge & 17.97 & 66.87 & 160 \\
& Guánica Dwarf & 17.95 & 66.83 & 13 \\
\hline
\end{tabular}

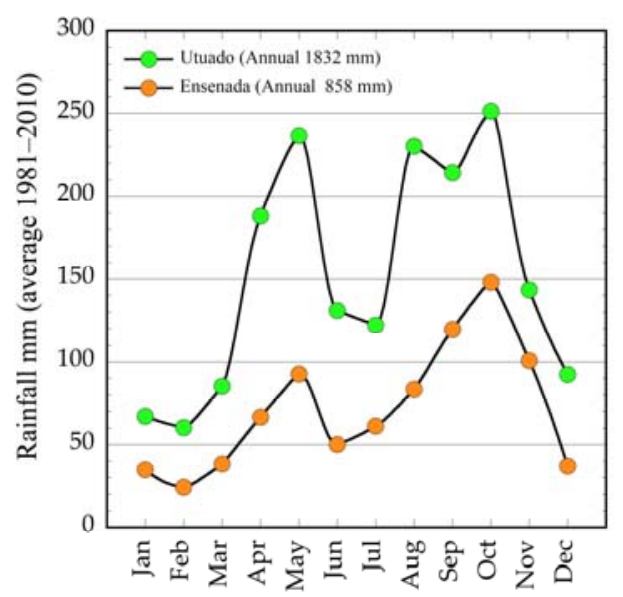

Figure 1. Average rainfall pattern of humid and dry karst sites.

The species sampled at each site were those more common, with high importance values $[16,19,22,23]$ (Table 2$)$. The number of species varied from site to site due to different areal extension, and the number of tree species growing on the mogote top. In total, we sampled 30 species from the northern, moist sites, and 26 species from the dry sites, representing 29 families and 18 orders. Only five species were sampled from both humidity sites.

For elemental analyses, we sampled at each site healthy mature leaves, without visible herbivore consumption, of trees from the upper forest canopy. Leaves were dried in the laboratory in a ventilated oven at $65{ }^{\circ} \mathrm{C}$ (3-7 days) and ground to pass an 18-mesh screen. Rock fragments on the forest floor were collected from each site. In the laboratory, rock samples were dissolved in $2 \mathrm{~N} \mathrm{HCl}$ for elemental analysis.

Elemental composition of samples was determined (C, N, S, P, K, Ca, Mg, Al, Mn, Fe) using standard methodology of the laboratory at the International Institute of Tropical Forestry [25]. Briefly, in acid digested samples, C, N, and S were determined using a LECO elemental analyzer, whereas $\mathrm{P}$ and cations were measured using Inductively coupled plasma atomic emission spectroscopy (ICP-AES) techniques.

In addition, the natural abundance of $C\left(\delta^{13} C\right)$ and $N$ isotopes $\left(\delta^{15} N\right)$ in leaves was determined at the Stable Isotope Laboratory of the University of Miami, Coral Gables, using mass spectrometric techniques. The $\delta^{13} \mathrm{C}$ values are used as indicators of long-term water use efficiency, because they are 
related to lower leaf conductance [26]. The leaf $\delta^{15} \mathrm{~N}$ values are related to the natural abundance of $\mathrm{N}$ isotopes in the substrate. More positive values point to higher rates of mineralization of organic $\mathrm{N}$ in the soil [27].

Element concentrations and $\mathrm{C}$ and $\mathrm{N}$ isotopic ratios of all species per site were submitted to a one-way analysis of variance and post-hoc tests for comparison of site averages. Inter-element correlations were estimated for the whole set of species to establish commonalities among sites. All statistical analyses were performed using the JMP statistical program.

Table 2. Species sampled at each site designated by name and municipality.

\begin{tabular}{|c|c|c|}
\hline Guajataca, Isabela & El Tallonal, Arecibo & Cambalache, Barceloneta \\
\hline $\begin{array}{l}\text { Calophyllum antillanum } \\
\text { Clusia rosea } \\
\text { Coccoloba pubescens } \\
\text { Comocladia glabra } \\
\text { Eugenia monticola } \\
\text { Lonchocarpus glaucifolius } \\
\text { Neolaugeria resinosa } \\
\text { Tetrazygia elaeagnoides }\end{array}$ & $\begin{array}{c}\text { Amyris elemifera } \\
\text { Coccoloba diversifolia } \\
\text { Exothea paniculata } \\
\text { Gymnanthes lucida } \\
\text { Pimenta racemosa var. grisea } \\
\text { Prunus myrtifolia } \\
\text { Tabebuia karsensis }\end{array}$ & $\begin{array}{l}\text { Coccoloba diversifolia } \\
\text { Crossopetalum rhacoma } \\
\text { Gymnanthes lucida } \\
\text { Krugiodendron ferreum } \\
\text { Sideroxylon salicifolium }\end{array}$ \\
\hline Nevarez, Toa Baja & Rio Lajas, Dorado & Hato Tejas, Bayamon \\
\hline $\begin{array}{c}\text { Ardisia obovata } \\
\text { Coccoloba diversifolia } \\
\text { Drypetes alba } \\
\text { Exothea paniculata } \\
\text { Garcinia portoricensis } \\
\text { Gaussia attenuata } \\
\text { Guapira fragrans } \\
\text { Licaria salicifolia } \\
\text { Ottoschultzia rodoxylon } \\
\text { Picramnia pentandra }\end{array}$ & $\begin{array}{l}\text { Ardisia obovata } \\
\text { Calyptranthes pallens } \\
\text { Coccoloba diversifolia } \\
\text { Cojoba arborea. } \\
\text { Exothea paniculata } \\
\text { Krugiodendron ferreum } \\
\text { Licaria salicifolia } \\
\text { Ottoschultzia rodoxylon } \\
\text { Sideroxylon salicifolium }\end{array}$ & $\begin{array}{l}\text { Coccoloba diversifolia } \\
\text { Eugenia monticola } \\
\text { Ficus citrifolia } \\
\text { Phyllanthus epiphyllanthu } \\
\text { Sideroxylon salicifolium }\end{array}$ \\
\hline Guánica Ridge F., Guánica & Guánica Dwarf F., Guánica & \\
\hline $\begin{array}{c}\text { Amyris elemifera } \\
\text { Bourreria succulenta } \\
\text { Bucida buceras } \\
\text { Elaeodendrum xylocarpa } \\
\text { Colubrina arborescens } \\
\text { Erythalis fruticosa } \\
\text { Erythroxylum areolatum } \\
\text { Exostemma caribaeum } \\
\text { Gymnanthes lucida } \\
\text { Pisonia albida } \\
\text { Tabebuia heterophylla } \\
\text { Thouinia striata var. portoricensis }\end{array}$ & $\begin{array}{c}\text { Amyris elemifera } \\
\text { Bourreria virgata } \\
\text { Canella winterana } \\
\text { Coccoloba diversifolia } \\
\text { Colubrina arborescens } \\
\text { Crossopetalum rhacoma } \\
\text { Erithalis fruticosa } \\
\text { Eugenia foetida } \\
\text { Ficus citrifolia } \\
\text { Jacquinia arborea } \\
\text { Jacquinia berteroi } \\
\text { Pisonia albida } \\
\text { Quadrella cynophallophora } \\
\text { Reynosia uncinata } \\
\text { Sideroxylon salicifolium } \\
\text { Stenostomum acutatum } \\
\text { Strumpfia maritima } \\
\text { Tabebuia heterophylla } \\
\text { Thrinax morrisii }\end{array}$ & \\
\hline
\end{tabular}

Plant names after [24].

\section{Results}

\subsection{Elemental Composition of the Substrate in Karst Areas in Puerto Rico}

The analysis of the elemental composition of rocks from different karst types of the northern karst belt published by Monroe [12] indicate that nearly $83 \%$ is constituted by $\mathrm{CaCO}_{3}$, and that they contain small but significant amounts of $\mathrm{Mg}, \mathrm{Al}$, and Fe. The elements $\mathrm{P}$ and particularly $\mathrm{K}$ are 
found at concentrations below $1 \mathrm{mmol} / \mathrm{kg}$. Rock fragments from the sites selected for vegetation sampling showed important differences in the proportion of minor elements. The sequence of elemental concentrations in the northern karst site confirmed the sequence $\mathrm{Ca}>>\mathrm{Mg}>\mathrm{Al}>\mathrm{Fe}$, corresponding to the average values from Monroe [12] (Figure 2). The samples from the southern karst had a similar elemental distribution, but Na was present in the Guánica samples at higher concentrations than any other site. Phosphorus concentration was at the same level in all samples $(\approx 1 \mathrm{mmol} / \mathrm{kg})$. Potassium reached concentrations around $10 \mathrm{mmol} / \mathrm{kg}$ in the southern samples, whereas it was always well below the $1 \mathrm{mmol} / \mathrm{kg}$ level in the northern karst samples.

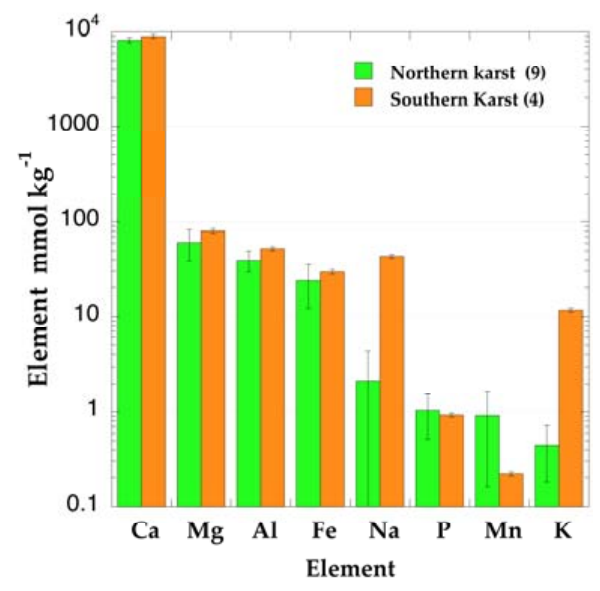

Figure 2. Average elemental composition of karst rocks from northern and southern sites in Puerto Rico.

The presence of non-calcareous sediments in cracks, holes, and crevices of the karstic substrate raised the question about their potential as a source of nutrients for the vegetation. They have been characterized in the Dominican Republic as lateritic in nature, with high concentrations of $\mathrm{Al}$ and Fe [1]. We do not have information on the elemental composition of those sediments in Puerto Rico. However, we calculated sediment concentrations from a nutrient inventory study in the northern karst belt [28]. Both $\mathrm{A}$ and $\mathrm{C}$ horizons indicate much higher concentrations of $\mathrm{Fe}, \mathrm{Mn}$, and $\mathrm{Al}$, and lower concentrations of $\mathrm{Ca}$ and $\mathrm{Mg}$ compared to those measured in calcareous rocks (Figure 3). The higher concentrations of $\mathrm{Ca}$ and $\mathrm{Mg}$ of the A horizon reveal the influence of in situ weathering of karst rocks. It appears then that these sediments may be a source of nutrients for the vegetation, and due to their clayey texture, they have much higher water retention and cation exchange capacities than the calcareous substrates.

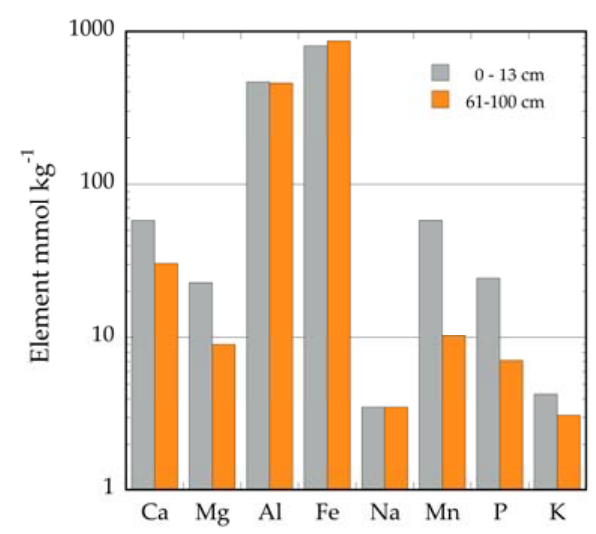

Figure 3. Elemental composition of clay soils on karst in El Tallonal, Arecibo, Puerto Rico. Values for the A horizon $(0-13 \mathrm{~cm})$ and the $C$ horizon $(61-100 \mathrm{~cm})$ were generated from [28]. 


\subsection{Leaf Elemental Composition}

The concentration of the main organic matter elements did not differ significantly between sites. The coefficients of variation were small for C $(<10 \%)$, intermediate for N and P (10 to 100\%), and large for S (>100\%) (Table 3). The concentration of metallic elements differed between sites for $\mathrm{K}, \mathrm{Ca}, \mathrm{Fe}$, $\mathrm{Mn}$, and $\mathrm{Na}$ (Table 4). The coefficients of variation were intermediate for $\mathrm{K}, \mathrm{Mg}, \mathrm{Ca}$, and Fe, large for $\mathrm{Na}$, and very large for $\mathrm{Al}$ and $\mathrm{Mn}(>250 \%)$. In the southern karst, average $\mathrm{K}$ concentration was higher, whereas for $\mathrm{Ca}$ and $\mathrm{Mn}$ concentration averages were lower than the overall mean. The average Na concentration in the Guánica Dwarf forest site was much larger than the overall mean, probably because this site is located near the coast line, under the influence of sea salt spray, and Na may be present in the rooting substrate, as indicated by the composition of the limestone from Guánica (Figure 2).

Table 3. Mean $( \pm \mathrm{SE})$ concentrations of main elements of organic matter $C$ in $\mathrm{mol} / \mathrm{kg}$, the rest in $\mathrm{mmol} / \mathrm{kg}$.

\begin{tabular}{cccccc}
\hline System & $\boldsymbol{n}$ & $\mathbf{C}$ & $\mathbf{N}$ & $\mathbf{S}$ & $\mathbf{P}$ \\
\hline Guajataca & 8 & $43.7(1.2)$ & $1247(163)$ & $60(12)$ & $18.7(1.9)$ \\
Tallonal & 7 & $43.7(1.0)$ & $1193(100)$ & $58(11)$ & $26.7(3.0)$ \\
Cambalache & 5 & $41.7(1.1)$ & $1315(217)$ & $102(37)$ & $22.8(3.1)$ \\
Nevarez & 10 & $41.7(0.7)$ & $1226(179)$ & $128(34)$ & $21.4(1.8)$ \\
Río Lajas & 10 & $43.2(0.6)$ & $1375(179)$ & $60(8)$ & $21.9(3.1)$ \\
Hato Tejas & 5 & $42.1(1.2)$ & $1144(103)$ & $77(18)$ & $23.1(3.7)$ \\
Guánica Ridge & 13 & $41.5(0.7)$ & $1361(168)$ & $75(10)$ & $25.4(3.7)$ \\
Guánica Dwarf & 26 & $42.3(0.5)$ & $991(65)$ & $94(26)$ & $20.5(2.5)$ \\
Overall mean & 84 & $42.4(0.3)$ & $1192(51)$ & $84(10)$ & $22.2(1.1)$ \\
Coefficient of Variation (CV) & & 6 & 39 & 105 & 46 \\
Analysis of Variance (ANOVA) & & $1.1(\mathrm{~ns})$ & $1.3(\mathrm{~ns})$ & $0.7(\mathrm{~ns})$ & $0.6(\mathrm{~ns})$ \\
\hline
\end{tabular}

ns, not significant.

Table 4. Mean ( \pm SE) concentrations of ash (\%) and metallic elements in leaves per site in $\mathrm{mmol} / \mathrm{kg}$.

\begin{tabular}{|c|c|c|c|c|c|c|c|c|c|}
\hline System & $n$ & Ash & $\mathbf{K}$ & $\mathrm{Mg}$ & $\mathrm{Ca}$ & Al & $\mathrm{Fe}$ & Mn & $\mathrm{Na}$ \\
\hline Guajataca & 8 & $6.8(1.3)$ & $132(20)$ & $110(17)$ & 450 (95) & $\begin{array}{c}91.6 \\
(86.7)\end{array}$ & $1.3(0.4)$ & $3.6(1.7)$ & $61(21)$ \\
\hline Tallonal & 7 & $7.7(1.4)$ & $162(29)$ & 114 (17) & $583(145)$ & $5.1(1.1)$ & $0.7(0.1)$ & $0.3(0.1)$ & $25(8)$ \\
\hline Cambalache & 5 & $10.9(1.6)$ & $102(32)$ & 148 (22) & $872(178)$ & $6.3(1.0)$ & $0.7(0.1)$ & $0.3(0.1)$ & 77 (19) \\
\hline Nevarez & 10 & $9.9(1.0)$ & 129 (20) & $154(36)$ & 708 (75) & $7.1(0.5)$ & $1.4(0.1)$ & $0.5(0.1)$ & $92(21)$ \\
\hline Río Lajas & 10 & $9.8(1.4)$ & $231(60)$ & $100(15)$ & $574(93)$ & $5.6(0.8)$ & $1.2(0.2)$ & $0.4(0.1)$ & $83(28)$ \\
\hline Hato Tejas & 5 & $9.4(1.6)$ & 206 (55) & $127(28)$ & 733 (148) & $7.1(1.1)$ & $1.4(0.2)$ & $0.3(0.1)$ & $90(22)$ \\
\hline Guánica Ridge & 13 & $8.4(0.7)$ & $315(41)$ & $162(36)$ & $409(45)$ & $4.1(0.4)$ & $0.6(0.1)$ & $0.3(0.1)$ & $40(12)$ \\
\hline Guánica Dwarf & 26 & $7.8(0.5)$ & $212(22)$ & 138 (17) & $340(40)$ & $4.6(0.4)$ & $0.6(0.0)$ & $0.5(0.1)$ & $221(34)$ \\
\hline Overall mean & 84 & $8.5(0.4)$ & $202(14)$ & $132(9)$ & 509 (33) & $13.6(8.4)$ & $0.9(0.1)$ & $0.7(0.2)$ & $112(14)$ \\
\hline $\mathrm{CV}$ & & 37 & 65 & 65 & 59 & 560 & 62 & 250 & 115 \\
\hline ANOVA (F; P) & & 1.3 (ns) & $3.3<0.01$ & 0.6 (ns) & $4.9<0.01$ & $1.4(\mathrm{~ns})$ & $6.3<0.01$ & $4.4<0.01$ & $5.4<0.01$ \\
\hline
\end{tabular}

Some species within the sampled set stand out, with concentrations of particular elements 2-3 times larger or smaller than the overall average (Table 5). These differences may be attributed to variations in element availability between sites, to differences in leaf age, or to actual physiological differences between species. Leaf age between samples of the same species at different sites cannot be discarded, as leaf sampling was conducted during several months; however, leaves collected were always fully expanded, healthy, and without visual signals of senescence or herbivory.

The design of the research was not oriented to differentiate species occurring at different sites; therefore, the data set is insufficient to conduct within species comparisons.

Elemental ratios between organic matter forming elements $(C, N, S, P)$ do not differ significantly between sites (Table 6). However, $\mathrm{K}$ to $\mathrm{Ca}$ ratios were larger and the $\mathrm{Ca}$ to $\mathrm{Mg}$ ratios lower for the 
two sites on the southern karst in correspondence with the relative elemental concentration of those elements measured in the calcareous rocks. The other sites showed $\mathrm{K}$ to $\mathrm{Ca}$ ratios ranging from 0.14 to 0.47 , revealing the high availability of $\mathrm{Ca}$ in the soil solution.

Table 5. Maximum and minimum concentrations of elements ( $\mathrm{mmol} / \mathrm{kg})$.

\begin{tabular}{|c|c|c|c|c|c|c|c|}
\hline Element & Species & Site & Max & Mean & Min & Species & Site \\
\hline $\mathrm{N}$ & Guapira fragrans & $\mathrm{N}$ & 2621 & & 565 & Erithalis fruticosa Grf, Gdf & \\
\hline$S$ & Gaussia attenuata & $\mathrm{N}$ & 367 & & 19 & Prunus myrtifolia & $\mathrm{T}$ \\
\hline $\mathrm{P}$ & Erythroxylum areolatum & Grf & 62 & 22 & 9 & Erithalis fruticosa Gdf, Grf & \\
\hline \multirow[t]{2}{*}{ K } & Bourreria succulenta & Grf & 615 & 202 & 51 & Sideroxylon salicifolium & $\mathrm{C}$ \\
\hline & Canella winterana & Gdf & 524 & & 50 & Strumpfia maritima & Gdf \\
\hline \multirow[t]{2}{*}{$\mathrm{Mg}$} & Pisonia albida & Grf, Gdf & 553 & 132 & 38 & Thrinax morrisii & Gdf \\
\hline & Guapira fragrans & $\mathrm{N}$ & 415 & & 22 & Licaria salicifolia $\mathrm{N}, \mathrm{RL}$ & \\
\hline $\mathrm{Ca}$ & Crossopetalum rhacoma & C & 1478 & 509 & 133 & Calophyllum brasiliense & G \\
\hline \multirow[t]{2}{*}{$\mathrm{Fe}$} & Tetrazygia elaeagnoides & G & 3.7 & 0.9 & 0.4 & Prunus myrtifolia & $\mathrm{T}$ \\
\hline & Krugiodendron ferreum & RL & 2.7 & & 0.3 & Clusia rosea & G \\
\hline \multirow[t]{2}{*}{ Mn } & Tetrazygia elaeagnoides & G & 13.2 & 0.7 & 0.04 & Prunus myrtifolia & $\mathrm{T}$ \\
\hline & Clusia rosea & G & 9.3 & & 0.04 & Jacquinia berteroi & Gdf \\
\hline
\end{tabular}

C, Cambalache; G, Guajataca; Gdf, Guánica dwarf forest; Grf, Guánica ridge forest; HT, Hato Tejas; N, Nevárez; RL, Río Lajas; T, Tallonal.

Table 6. Molar elemental ratios of leaves from trees on calcareous substrates.

\begin{tabular}{cccccccc}
\hline Site & $\boldsymbol{n}$ & $\mathbf{C} / \mathbf{N}$ & $\mathbf{C} / \mathbf{P}$ & $\mathbf{C} / \mathbf{S}$ & $\mathbf{N} / \mathbf{P}$ & $\mathbf{K} / \mathbf{C a}$ & $\mathbf{C a} / \mathbf{M g}$ \\
\hline Guajataca & 8 & 39 & 2507 & 900 & 67 & 0.40 & 4.08 \\
Tallonal & 7 & 39 & 1831 & 996 & 46 & 0.47 & 5.09 \\
Cambalache & 5 & 35 & 1992 & 654 & 58 & 0.14 & 6.43 \\
Nevarez & 10 & 39 & 2086 & 505 & 56 & 0.20 & 7.35 \\
Río Lajas & 9 & 39 & 2514 & 838 & 67 & 0.34 & 7.34 \\
Hato Tejas & 5 & 38 & 2006 & 717 & 53 & 0.31 & 6.10 \\
Guánica Ridge forest & 13 & 37 & 2082 & 639 & 56 & 0.91 & 3.29 \\
Guánica Dwarf forest & 25 & 47 & 2819 & 744 & 59 & 0.87 & 2.90 \\
Overall mean & 84 & 41 & 2328 & 732 & 58 & 0.59 & 4.63 \\
ANOVA (F; P) & & $1.0(\mathrm{~ns})$ & $1.0(\mathrm{~ns})$ & $1.5(\mathrm{~ns})$ & $1.3(\mathrm{~ns})$ & $3.4<0.01$ & $4.2<0.01$ \\
\hline
\end{tabular}

ns, not significant.

Inter-Element Correlations

The correlation between leaf $\mathrm{N}$ and $\mathrm{P}$ was positive and significant, as usually reported for forest foliage throughout the world [29] (Figure 4). As expected, the Ash\% was inversely correlated with C concentration $\left(R^{2}\right.$ adj $\left.=0.57\right)$, but positively correlated with Ca $\left(R^{2}\right.$ adj $\left.=0.72\right), \operatorname{Mg}\left(R^{2}\right.$ adj $\left.=0.24\right)$, and $\mathrm{Mn}\left(R^{2}\right.$ adj $\left.=0.08\right)$. Clearly $\mathrm{Ca}$ and $\mathrm{Mg}$ were the main constituents of ash, explaining more than $80 \%$ of the variance.

We found an unexpected highly significant correlation between $\mathrm{Ca}$ and $\mathrm{Al}$ concentrations for all sites (Figure 5). Only two species departed strongly from this relationship, T. elaeagnoides and L. glaucifolius, both from the Guajataca site. This relationship deserves special attention because of its implications regarding the mechanisms of nutrient uptake from karstic complex substrates. Considering the low concentrations of $\mathrm{Al}, \mathrm{Fe}$, and $\mathrm{Mn}$ in the calcareous substrate in karst areas, it is not surprising that these elements are only a minor component of leaf ash of trees growing there. If clayey 
sediment accumulated in cracks and crevices of the rocky substrates on mogote tops was a source of those metallic elements, we expected higher concentrations of them in tree foliage, but that was not the case in our data set, with the exception of T. elaeagnoides, identified as a metal accumulator (Table 5).

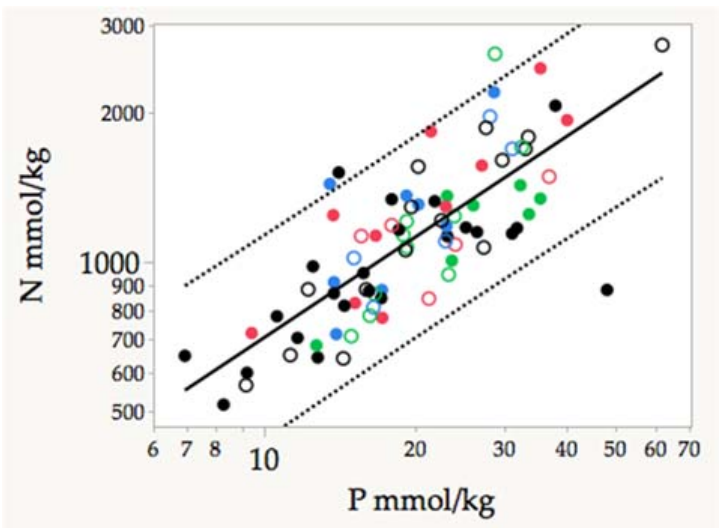

Figure 4. Correlation between $\mathrm{N}$ and $\mathrm{P}$ concentrations in adult leaves from different karst forest species. Guánica forests: dwarf, Black; ridge, empty black; Guajataca, solid blue; Cambalache, empty blue; Tallonal solid green; Nevarez, empty green; Río Lajas, solid red; Hato Tejas, empty red. $\log (\mathrm{N} \mathrm{mmol} / \mathrm{kg})=5.011+0.672 \times \log (\mathrm{P}) ;$ Fratio $=120 ; \mathrm{F}<p<0.001 ; R^{2}$ adj $=0.592 ; n=83$.

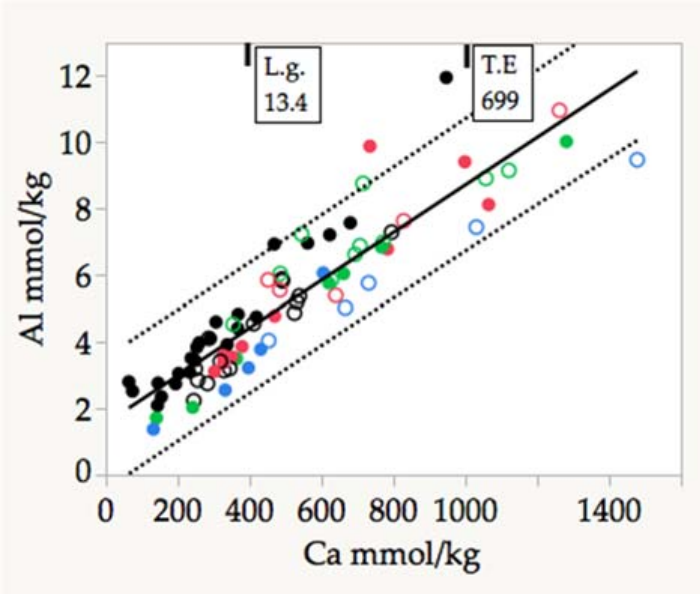

Figure 5. Linear correlation between the concentrations of $\mathrm{Ca}$ and $\mathrm{Al}$ in adult leaves of karst tree species. The arrows indicate the values of $\mathrm{Al}$ accumulators which were not included in the regression. $\mathrm{Al}(\mathrm{mmol} / \mathrm{kg})=1.55+0.007 \times \mathrm{Ca}(\mathrm{mmol} / \mathrm{kg}) \cdot R^{2}$ adj $=0.825 ; \mathrm{F}=379, p<0.0001, n=81$. Symbols are the same as in Figure 4.

\subsection{Isotopic Ratios}

The $\delta^{13} \mathrm{C}$ values did not differ significantly in the northern karst forest locations (Figure 6). The only outlier was represented by $C$. rosea, a tree with crassulacean acid metabolism [30] commonly occurring in the northern karst belt forests. It was excluded from average calculations. As expected, the two sites on the southern karst had significantly higher $\delta^{13} \mathrm{C}$ values, because of the drier conditions under which this vegetation grows. Average $\delta^{13} \mathrm{C}$ of leaves from humid karst was $-30.83 \pm 1.85 \%$ o $(n=52)$, and from dry karst was $-27.37 \pm 1.16 \%$, the difference was highly significant (Tukey Honest Significant Difference test $p=0.01$ ).

The distribution of $\delta^{15} \mathrm{~N}$ values varied significantly among sites, showing a more complex pattern than that of the carbon isotopes (Figure 6). The sites on southern karst and the Nevarez site showed positive values, whereas the rest of the sites had negative $\delta^{15} \mathrm{~N}$ average values. Overall averages were 
positive in the dry karst, $3.49 \pm 2.20 \%$ o $(n=40)$, and slightly negative, $-0.28 \pm 1.82 \%$ o $(n=51)$, in the moist karst forests. The degree of overlap was higher in the case of ${ }^{15} \mathrm{~N}$, revealing the more complex regulation of this factor under natural conditions.
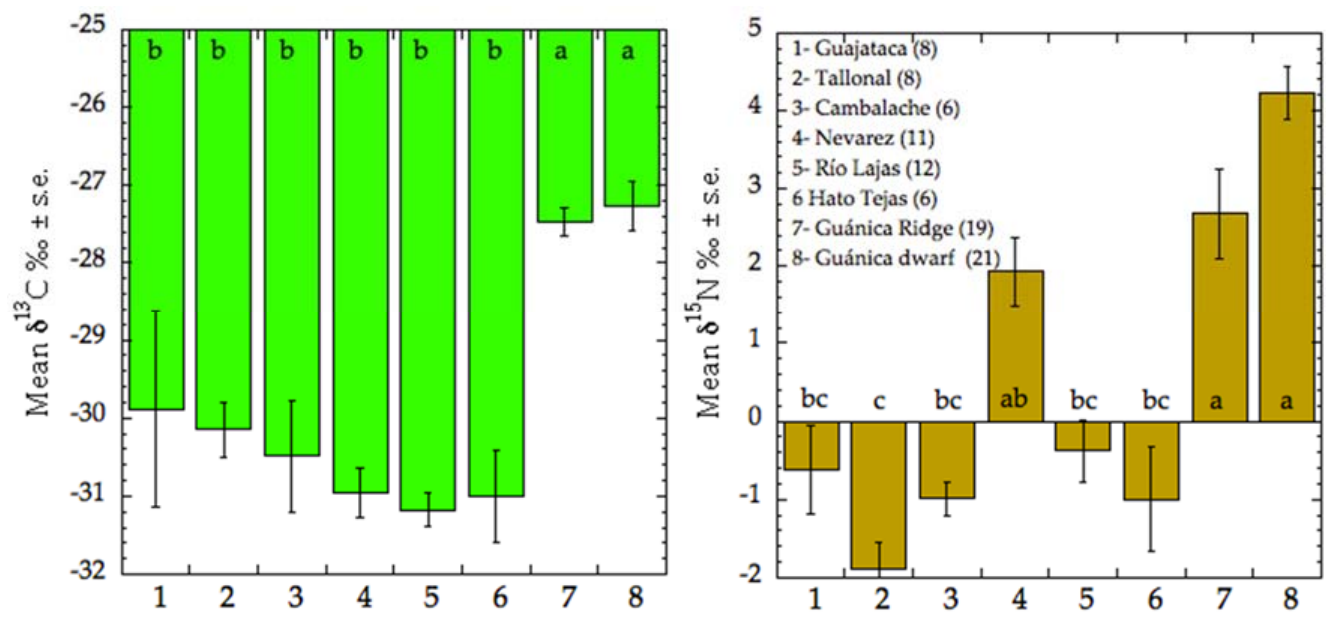

Figure 6. Average \pm SE. values of $\mathrm{N}$ and $\mathrm{C}$ isotopes in adult leaves from different karst forests in Puerto Rico. Columns with the same letter at the base indicate statistical similarity (Tukey Honest Significant Difference, $p=0.01$ ).

\section{Discussion}

\subsection{Comparison between Humid and Dry Tropical Forests on Contrasting Soils}

Comparison of the dry/moist karst leaf data with other assessments of leaf nutrient concentration in wet and seasonally dry tropical forests shows, in general, that karst forests in Puerto Rico are more limited by $\mathrm{P}$ than $\mathrm{N}$, judging by their high $\mathrm{N} / \mathrm{P}$ ratios, similar to those reported for P-poor forests in the Amazon basin (Table 7). A lower montane rain forest on volcanic soils in Puerto Rico (El Verde, Luquillo Experimental Forest) [31] has much higher concentrations of $\mathrm{K}$ and $\mathrm{P}$, and lower $\mathrm{N} / \mathrm{P}$ ratio than both the humid and dry karst leaves. Moreover, dry and humid karst leaves have quite similar average concentrations of $\mathrm{Mg}, \mathrm{P}$, and $\mathrm{N}$, and large $\mathrm{N} / \mathrm{P}$ ratios. Remarkably, dry karst leaves are richer in $\mathrm{K}$, but poorer in Ca compared to humid karst leaves. Possible explanation for the high $\mathrm{K}$ may be the coastal location of the dry karst sites, whereas the higher Ca concentration in moist karst is probably associated with the prevailing humidity of the substrate, which leads to higher availability of soluble Ca.

Table 7. Average leaf nutrient concentrations in a range of humid and dry tropical forests (mmol/ $\mathrm{kg})$.

\begin{tabular}{|c|c|c|c|c|c|c|c|c|}
\hline Site & $n$ & $\mathbf{N}$ & $\mathbf{P}$ & $\mathbf{K}$ & $\mathrm{Ca}$ & $\mathrm{Mg}$ & $\mathbf{N} / \mathbf{P}$ & Reference \\
\hline \multicolumn{9}{|l|}{ Rainforests } \\
\hline Oxisols & 462 & 1371 & 26 & - & - & - & 58 & [32] \\
\hline Other & 110 & 1307 & 37 & - & - & - & 38 & [32] \\
\hline French Guyana & 45 & 1143 & 23 & - & - & - & 54 & [33] \\
\hline El Verde PR & 41 & 1156 & 26 & 291 & 257 & 163 & 46 & {$[31]$} \\
\hline \multicolumn{9}{|c|}{ Seasonally dry forest } \\
\hline Chamela, Mexico & 19 & 1281 & 33 & - & - & - & 40 & [34] \\
\hline Goias, Brazil & 13 & 1680 & 46 & 293 & 389 & 89 & 43 & {$[35]$} \\
\hline \multicolumn{9}{|c|}{ Karst region southwestern China } \\
\hline & 121 & 1224 & 47 & 210 & 517 & 125 & 26 & [36] \\
\hline Karst moist forest & 44 & 1243 & 22 & 150 & 640 & 123 & 59 & Present study \\
\hline Karst dry forest & 38 & 1123 & 21 & 248 & 360 & 141 & 58 & Present study \\
\hline
\end{tabular}


The average values of $\mathrm{C}, \mathrm{N}$, and $\mathrm{P}$ from our data set are similar to those reported by Hättenschwiler et al. [33] for 45 tree species in a lowland wet neotropical forest. The range of variation of the species from karst forests (Table 3) is the same for $\mathrm{C}$ but much larger for $\mathrm{N}$ and $\mathrm{P}$ than that of the neotropical forest in French Guiana. The average N/P ratio of their data set amounts to 54, slightly lower than the average of our data set (58), but the $\mathrm{C} / \mathrm{N}$ and $\mathrm{C} / \mathrm{P}$ ratios are similar.

Absolute concentrations of $\mathrm{N}$ and $\mathrm{P}$ in karst forest species are also lower than those reported for many species from forests on P-poor oxisols in Amazonas by Townsend et al. [32], but the N/P ratio is quite similar, amounting to 58 on a molar basis. It may be concluded from these comparisons with moist and wet tropical forest sites that the karts forests from Puerto Rico are relatively limited by P.

Most seasonally dry forest soils in the neotropics are comparatively rich in $\mathrm{Ca}$, but are as low in $\mathrm{P}$ as the karst forest reported here. Leaf P concentrations in seasonally dry forest in Chamela, Mexico [34], and a deciduous forest on calcareous outcrops in the cerrado of Goias in Brazil [35], are much higher than the values reported here (Table 7). Therefore, their average leaf $\mathrm{N} / \mathrm{P}$ ratios are much lower than those measured in our karst forests.

A recent study from vegetation on karst in China slightly above $26^{\circ} \mathrm{N}$ reports surprisingly much higher P concentrations in leaves, and lower N/P values than those reported here for Puerto Rico [36]. Concentrations of the other elements are within the same range as those reported here (Table 7).

The influence of element availability in substrate is suggested by the fact that the species with higher K concentrations, and the mean of site values, correspond to the Guánica Ridge and Dwarf forests, in agreement with the results of rock analyses.

Physiological differences may be indicated for the case of Tetrazygia elaeagnoides, one of the few Melastomataceae tree species recorded for mogote tops in the northern karst belt [17,24]. This species is a strong $\mathrm{Al}$ accumulator, a characteristic common among the members of the Melastomataceae, but it is remarkable that it also showed the highest concentrations of Fe and Mn in the whole data set. In addition, the two legumes included in this data set, P. arboreum and L. glaucifolius, are among the species with highest concentrations of $\mathrm{N}$.

Concentrations of heavy metals (Fe and $\mathrm{Mn}$ ) in the Liu et al. study [36] were also about two times higher than in the present paper (2 vs. $0.7 \mathrm{mmol} / \mathrm{kg}$ ). Data on $\mathrm{Al}$ in karst vegetation were not found in the available literature. Excluding the $\mathrm{Al}$ accumulators sampled in Guajataca site, concentrations reported here are below $10 \mathrm{mmol} / \mathrm{kg}$ (Table 4), much lower than values reported by Masunaga et al. [37] for non-accumulator trees in Sumatra rain forest (21.5).

\subsection{The Ca/Al Relationship: Al Accumulators in Limestone Forests}

In an extensive analysis of tree material in a tropical rain forest in West Sumatra, Masunaga et al. $[37,38]$ were able to identify a wide variation in Al accumulation in tree foliage. They modified the criteria for defining Al-accumulator species using the $1 \mathrm{~g} / \mathrm{kg}$ leaf concentration boundary (37 mmol/ $\mathrm{kg})$, introducing categories of accumulators between 1 and $3 \mathrm{~g} \mathrm{Al} / \mathrm{kg}(37-111 \mathrm{mmol} / \mathrm{kg})$ and strong accumulators with $>3 \mathrm{~g} \mathrm{Al} / \mathrm{kg}(>111 \mathrm{mmol} / \mathrm{kg})$. For non-Al accumulators, Al was positively correlated with $\mathrm{Ca}(r=0.62, n=469)$ and $\mathrm{Mg}(r=0.23)$. For strong accumulators, the correlation was not significant at the $1 \%$ level. For the non-accumulators, Masunaga et al. [37] indicate that the $\mathrm{Al} / \mathrm{Ca}$ ratio averages $0.04 \pm 0.02$, whereas for our data set this ratio averaged $0.011 \pm 0.005$, due to the much higher Ca concentration in leaf tissues (509 vs. $367 \mathrm{mmol} \mathrm{Ca/kg).}$

The elemental concentration of leaves from rainforests on Ca-rich soils in West Sumatra is characterized by a large range of variation of most metals, particularly $\mathrm{Al}, \mathrm{Fe}$, and $\mathrm{Mn}$, and includes several metal accumulator species [38]. The rainforest leaves of the West Sumatra forest have quite similar concentrations of $\mathrm{P}, \mathrm{S}, \mathrm{K}, \mathrm{Ca}$, and $\mathrm{Mg}$, but much higher concentrations of $\mathrm{Al}, \mathrm{Fe}$, and $\mathrm{Mn}$ than the karst forest species reported here. These comparisons show that in spite of huge differences in rainfall, the main factor regulating concentration of cations in leaves is the elemental availability from soil, with the exception of metal accumulators. Aluminum accumulators are numerous in the West Sumatra data set [37], whereas only two tree species were detected in the karst forests studied. 
Why is there such a clear relationship between $\mathrm{Ca}$ and $\mathrm{Al}$ concentrations in non-Al accumulators, both in rain and moist and dry karst forests? We suggest that root activity in calcareous substrate includes the secretion of organic acids in the rhizosphere, leading to the dissolution of the carbonatic rocks, thereby releasing $\mathrm{Ca}$ and other metals present, as well as $\mathrm{P}$. This is one of the specific mechanisms described to counteract low Fe availability in calcareous soils [14]. Organic acids may act as chelating agents facilitating Fe uptake, but also the uptake of other metallic cations present in the soil solution. In addition to the high Al-Ca correlation, our data set shows that Ca is linearly, but more weakly, related to the concentrations of $\mathrm{Mg}$ and Fe $(p=0.05)$, but no relationship was detected with $\mathrm{Mn}$.

\subsection{Isotopic Relationships}

The significant higher values of $\delta^{13} \mathrm{C}$ in both dry karst forest sites were expected. The restrictions in water supply determine long-term reductions in stomatal conductance leading to reduction in ${ }^{13} \mathrm{C}$ discrimination in the photosynthetic process [26].

Variation of $\mathrm{N}$ isotopic values under natural conditions can be associated with intrinsic biological characteristics of the species involved or with ecosystems nutrient cycling properties:

(a) Occurrence of mycorrhiza may decrease values compared to non-mycorrhizal plants [39,40].

(b) Symbiotic $\mathrm{N}_{2}$ fixation (as in legumes-Rhizobium association) results in lower values because this process does not discriminate against the heavier $\mathrm{N}$ isotope [41].

(c) Conditions inhibiting denitrification processes (water saturated soils) lead to more negative values in vegetation, the opposite effect occurs in drier areas where denitrification operates freely $[42,43]$.

(d) High levels of $\mathrm{N}$ availability and P limitation lead to higher values [40,44].

There are few studies on mycorrhizal associations in woody vegetation on calcareous substrates in the Caribbean. However, a recent report concluded that seasonal rainfall has a strong influence on the diversity of mycorrhizal fungi but not on infectivity [45]. Therefore, we may assume that mycorrhiza is not responsible for the differences observed. Furthermore, legumes represent only a small fraction of the species analyzed ( 2 out of 56). Finally, P deficiencies assessed through the $\mathrm{N}$ to $\mathrm{P}$ ratios were similar for moist and dry sites. The main factor determining lower leaf $\delta^{15} \mathrm{~N}$ values in the moist north karst species compared to the drier southern karst region seems to be the difference in rainfall. In mogote tops, however, humidity conditions may be highly heterogeneous due to low water retention capacity of calcareous substrates, and the random occurrence of rock cracks and crevices where water may be retained.

\section{Conclusions}

- Karst vegetation in Puerto Rico appears to be P limited based both on lower P concentrations and high N/P ratios in leaves. The latter are similar to those of rain forests on P poor soils.

- Source of cations originate both from calcareous rocks (Ca and $\mathrm{Mg}$ ) and allochthonous sediments from volcaniclastic rocks ( $\mathrm{Al}$ and $\mathrm{Fe}$ ).

- Calcium is the predominant cation in leaf tissue and its concentration explains more than $70 \%$ of the variation in ash content.

- The leaf concentrations of $\mathrm{K}$ and $\mathrm{Na}$ are larger in the dry karst sites, probably because of their coastal location. Calcium was higher in moist karst sites, probably due the larger availability of soluble Ca in the substrate.

- The tree species of both moist and dry karst forest accumulate small amounts of Al, which is linearly correlated with the total accumulation of $\mathrm{Ca}$ in leaf tissue. This correlation may derive from the process of element solubilization in the rhizosphere driven by the secretion of organic acids.

- The $\delta^{13} \mathrm{C}$ values of leaf tissue are significantly higher in the dry karst forest, revealing the limitations of water supply. 
- The $\delta^{15} \mathrm{~N}$ values of leaf tissue were, with one exception, significantly lower in moist karst sites. The probable cause is that denitrification tends to predominate in drier environments.

Acknowledgments: Field work and chemical analyses were conducted using IITF facilities. Alberto Rodríguez (formerly at IITF) provided assistance during field work, and Marcos Caraballo (University of Puerto Rico) helped with the species identification. Edwin López Soto from IITF lab revised the methods section and the whole data set.

Author Contributions: E.M., E.C. and A.E.L. conceived the project; E.M. and E.C. conducted the field sampling; E.M. conducted the statistical analyses and wrote the paper with contributions from E.C. and A.E.L.

Conflicts of Interest: The authors declare no conflict of interest.

\section{References}

1. Goldich, S.S.; Bergquist, H.R. Aluminous Lateritic Soil of the Sierra de Bahoruco Area Dominican Republic, W. I.; Bulletin 953-C; United States Department of the Interior, Geological Survey, United States Government Printing Office: Washington, DC, USA, 1947.

2. Asprey, G.F.; Robbins, R.G. The vegetation of Jamaica. Ecol. Monogr. 1953, 23, 359-412. [CrossRef]

3. Lötschert, W. Die Übereinstimmung von geologischer Unterlage und Vegetation in der Sierra de los Organos (Westkuba). Ber. Deutsch. Bot. Ges. 1958, 71, 55.

4. Lugo, A.E.; Miranda Castro, L.; Vale, A.; López, T.M.; Hernández Prieto, E.; García Martinó, A.; Puente Rolón, A.R.; Tossas, A.G.; McFarlane, D.A.; Miller, T.; et al. Puerto Rican Karst-A Vital Resource; General Technical Report WO-65; USDA Forest Service: Washington, DC, USA, 2001.

5. Díaz del Olmo, F.; Cámara Artigas, R. Karst Tropical de Colinas, Tipología y Evolución en el Pliocuaternario en República Dominicana; Flor, G., Ed.; Actas de la XI Reunión Nacional de Cuaternario, XI Reunión Nacional de Cuaternario: Oviedo, Spain, 2003; pp. 123-129.

6. Day, M. Human interaction with Caribbean karst landscapes: Past, present and future. Acta Carsologica 2010, 39, 137-146. [CrossRef]

7. Kelly, D.L.; Tanner, E.V.J.; Kapos, V.; Dickinson, T.A.; Goodfriend, G.A.; Fairbairn, P. Jamaican Limestone Forests: Floristics, structure and environment of three examples along a rainfall gradient. J. Trop. Ecol. 1988, 4, 121-156. [CrossRef]

8. Borhidi, A. Dry coastal ecosystems of Cuba. In Ecosystems of the World. Dry Coastal Ecosystems Africa, America, Asia and Oceania; van der Maarel, E., Ed.; Elsevier: Amsterdam, The Netherlands, 1993; Volume 2, pp. 423-452.

9. Areces-Mallea, A.E.; Weakley, A.S.; Li, X.; Sayre, R.G.; Parrish, J.D.; Tipton, C.V.; Bouche, T. A Guide to Caribbean Vegetation Types: Preliminary Classification System and Descriptions; Panagopoulos, N., Ed.; The Nature Conservancy International Headquarters: Washington, DC, USA, 1999; p. 166.

10. Alemán-Gonzalez, W.B. Karst Map of Puerto Rico; US Geological Survey: Reston, VA, USA, 2010.

11. Briggs, R.P. The blanket sands of northern Puerto Rico. In Proceedings of the Transactions of the 3rd Caribbean Geology Conference, Kingston, Jamaica, 2-11 April 1962; Jamaica Geological Survey Publication: Kingston, Jamaica, 1966.; pp. 60-69.

12. Monroe, W.H. The Karst Landforms of Puerto Rico; U.S. Geological Survey Professional Paper 899; Government Printing Office: Washington, DC, USA, 1976; p. 69.

13. Mengel, K.; Kirkby, E.A. Principles of Plant Nutrition, 5th ed.; Kluwer Academic Publishers: Dordrecht, The Netherlands, 2001; p. 849.

14. Marschner, H. Mineral Nutrition of Higher Plants, 2nd ed.; Academic Press: Cambridge, MA, USA, 1995.

15. Kinzel, H. Influence of limestone, silicates and soil $\mathrm{pH}$ on vegetation. In Physiological Plant Ecology III. Responses to Chemical and Biological Environment; Lange, O.L., Nobel, P.S., Osmond, C.B., Ziegler, H., Eds.; Encyclopedia of Plant Physiology; Springer: Berlin, Germany, 1983; Volume 12, pp. 201-244.

16. Medina, E.; Cuevas, E.; Molina, S.; Lugo, A.E.; Ramos, O. Structural variability and species diversity of a dwarf Caribbean dry forest. Caribb. J. Sci. 2012, 46, 203-215. [CrossRef]

17. Alvarez Ruiz, M.; Acevedo Rodriguez, P.; Vazquez, M. Quantitative description of the structure and diversity of the vegetation in the Limestone Forest of Rio Abajo, Arecibo-Utuado, Puerto Rico. Acta Cient. 1997, 11, $21-66$. 
18. Acevedo-Rodríguez, P.; Axelrod, F.S. Annotated checklist for the tracheophytes of Río Abajo forest reserve, Puerto Rico. Caribb. J. Sci. 1999, 35, 265-285.

19. Murphy, P.G.; Lugo, A.E. Structure and biomass of a subtropical dry forest in Puerto Rico. Biotropica 1986, 18, 89-96. [CrossRef]

20. Monsegur-Rivera, O.A. Vascular Flora of the Guánica dry Forest, Puerto Rico. Master's Thesis, University of Puerto Rico, Mayagüez Campus, San Juan, Puerto Rico, 2009.

21. Chinea, J.D. The Forest Vegetation of the Limestone Hills of Northern Puerto Rico. Ph.D. Thesis, Cornell University, Ithaca, NY, USA, 1980.

22. Aukema, J.E.; Carlo, T.A.; Collazo, J.A. Landscape assessment of tree communities in the northern karst region of Puerto Rico. Plant Ecol. 2007, 189, 101-115. [CrossRef]

23. Molina Colon, S.; Lugo, A.E. Recovery of a subtropical dry forest after abandonment of different land uses. Biotropica 2006, 38, 354-364. [CrossRef]

24. Axelrod, F.S. A Systematic Vademecum to the Vascular Plants of Puerto Rico; Botanical Research Institute of Texas: Fort Worth, TX, USA, 2011.

25. Sánchez, M.J.; Lopez, E.; Lugo, A.E. Chemical and Physical Analysis of Selected Plants and Soils from Puerto Rico (1981-2000); Gen. Tech. Rep. GTR-IITF-45; U.S. Department of Agriculture, Forest Service, International Institute of Tropical Forestry: Rio Piedras, PR, USA, 2015; p. 85.

26. Farquhar, G.D.; Hubick, K.T.; Condon, A.G.; Richards, R.A. Carbon isotope fractionation and plant water use efficiency. In Stable Isotopes in Ecological Research; Rundel, P.W., Ehleringer, J.R., Nagy, K.A., Eds.; Ecological Studies; Springer: New York, NY, USA, 1989; Volume 68, pp. 21-40.

27. Handley, L.L.; Raven, J.A. The use of natural abundance of nitrogen isotopes in plant physiology and ecology. Plant Cell Environ. 1992, 15, 965-985. [CrossRef]

28. Viera Martínez, C.A.; Abelleira Martínez, O.J.; Lugo, A.E. Estructura y química del suelo en un bosque de Castilla elastica en el carso del norte de Puerto Rico: Resultados de una calicata. Acta Cient. 2008, 22, $29-35$.

29. McGroddy, M.E.; Daufresne, T.; Hedin, L.O. Scaling of C:N:P stoichiometry in forests worldwide: Implications of terrestrial Redfield-type ratios. Ecology 2004, 85, 2390-2401. [CrossRef]

30. Tinoco-Ojanguren, C.; Vázquez-Yánes, C. Especies CAM in la selva húmeda tropical de Los Tuxtlas, Veracruz. Bol. Soc. Bot. Mex. 1983, 45, 150-153.

31. Ovington, J.D.; Olson, J.S. Biomass and Chemical Content of EI Verde Lower Montane Rain Forest Plants. In A Tropical Rain Forest: A Study of Irradiation and Ecology at El Verde, Puerto Rico; Odum, H.T., Pigeon, R.F., Eds.; National Technical Information Service: Springfield, VA, USA, 1970; Volume H-2, pp. H53-H75.

32. Townsend, A.R.; Cleveland, C.C.; Asner, G.P.; Bustamante, M.M.C. Controls over foliar N:P ratios in tropical rain forests. Ecology 2007, 88, 107-118. [CrossRef]

33. Hättenschwiler, S.; Aeschlimann, B.; Coûteaux, M.-M.; Roy, J.; Bonal, D. High variation in foliage and leaf litter chemistry among 45 tree species of a neotropical rainforest community. New Phytol. 2008, 179, 165-175.

34. Rentería, L.Y.; Jaramillo, V.J. Rainfall drives leaf traits and leaf nutrient resorption in a tropical dry forest in Mexico. Oecologia 2011, 165, 201-211. [CrossRef] [PubMed]

35. Rossatto, D.R.; Alvim Carvalho, F.; Haridasan, M. Soil and leaf nutrient content of tree species support deciduous forests on limestone outcrops as a eutrophic ecosystem. Acta Bot. Bras. 2015, 29, 231-238. [CrossRef]

36. Liu, C.; Liu, Y.; Guo, K.; Wang, S.; Yang, Y. Concentrations and resorption patterns of 13 nutrients in different plant functional types in the karst region of south-western China. Ann. Bot. 2014, 113, 873-885. [CrossRef] [PubMed]

37. Masunaga, T.; Kubota, D.; Hotta, M.; Wakatsuki, T. Mineral composition of leaves and bark in aluminum accumulators in a tropical rain forest in Indonesia. Soil Sci. Plant Nutr. 1998, 44, 347-358. [CrossRef]

38. Masunaga, T.; Kubota, D.; Hotta, M.; Wakatsuki, T. Nutritional characteristics of mineral elements in tree species of tropical rain forest, west Sumatra, Indonesia. Soil Sci. Plant Nutr. 1997, 43, 405-418. [CrossRef]

39. Högberg, P. ${ }^{15} \mathrm{~N}$ natural abundance in soil-plant systems. New Phytol. 1997, 137, 179-203. [CrossRef]

40. Craine, J.M.; Elmore, A.J.; Aidar, M.P.M.; Bustamante, M.; Dawson, T.E.; Hobbie, E.A.; Kahmen, A.; Mack, M.C.; McLauchlan, K.K.; Michelsen, A.; et al. Global patterns of foliar nitrogen isotopes and their relationships with climate, mycorrhizal fungi, foliar nutrient concentrations, and nitrogen availability. New Phytol. 2009, 183, 980-992. [CrossRef] [PubMed] 
41. Shearer, G.; Kohl, D.H. $\mathrm{N}_{2}$-fixation in field settings: Estimations based on natural ${ }^{15} \mathrm{~N}$ abundance. Aust. J. Plant Physiol. 1986, 13, 699-756. [CrossRef]

42. Martinelli, L.A.; Piccolo, M.C.; Townsend, A.R.; Vitousek, P.M.; Cuevas, E.; Mcdowell, W.; Robertson, G.P.; Santos, O.C.; Treseder, K. Nitrogen stable isotopic composition of leaves and soil: Tropical versus temperate forests. Biogeochemistry 1999, 46, 45-65. [CrossRef]

43. Medina, E.; Izaguirre, M.L. $\mathrm{N}_{2}$-fixation in tropical American savannas evaluated by the natural abundance of ${ }^{15} \mathrm{~N}$ in plant tissues and soil organic matter. Trop. Ecol. 2004, 45, 87-95.

44. Nardoto, G.B.; Ometto, J.P.H.B.; Ehleringer, J.R.; Higuchi, N.; Bustamante, M.M.; Martinelli, L.A. Understanding the influences of spatial patterns on $\mathrm{N}$ availability within the Brazilian Amazon forest. Ecosystems 2008, 11, 1234-1246. [CrossRef]

45. Guadarrama, P.; Castillo, S.; Ramos-Zapata, J.A.; Hernández-Cuevas, L.V.; Camargo-Ricalde, S.L. Arbuscular mycorrhizal fungal communities in changing environments: The effects of seasonality and anthropogenic disturbance in a seasonal dry forest. Pedobiologia 2014, 57, 87-95. [CrossRef]

(C) 2017 by the authors. Licensee MDPI, Basel, Switzerland. This article is an open access article distributed under the terms and conditions of the Creative Commons Attribution (CC BY) license (http:/ / creativecommons.org/licenses/by/4.0/). 